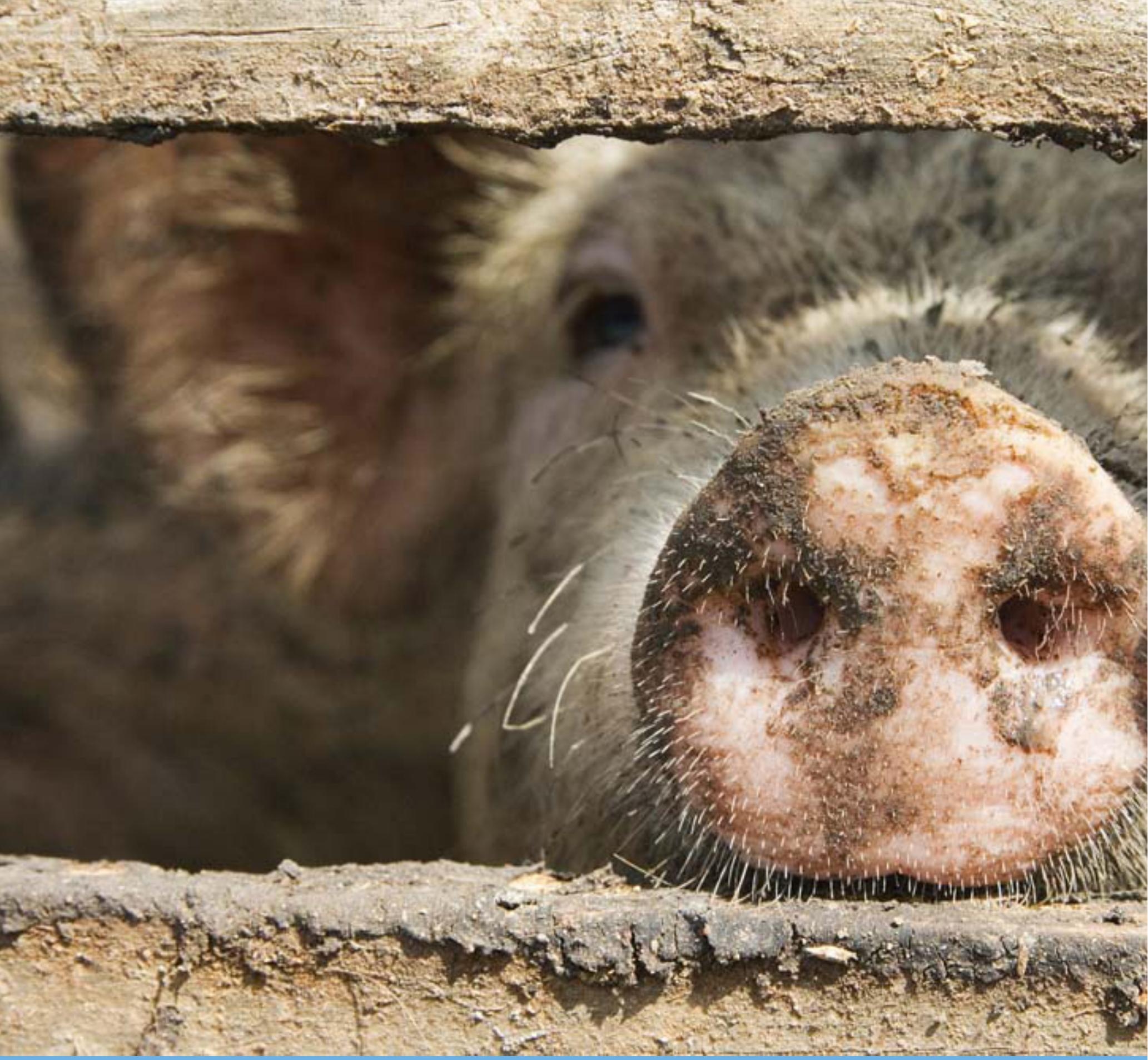

\title{
Plasma in diets for weaned pigs
}




\section{Plasma in diets for weaned pigs}

P. Bikker, R.J.G.A. Verheijen, G.P. Binnendijk 
P. Bikker, R.J.G.A. Verheijen, G.P. Binnendijk, 2018. Plasma in diets for weaned pigs. Wageningen Livestock Research, Report 1122.

This report can be downloaded for free at https://doi.org/10.18174/459941 or at www.wur.nl/livestock-research (under Wageningen Livestock Research publications).

(C) 2018 Wageningen Livestock Research

P.O. Box 338, 6700 AH Wageningen, The Netherlands, T +31 (0)317 483953 ,

E info.livestockresearch@wur.nl, www.wur.nl/livestock-research. Wageningen Livestock Research is part of Wageningen University \& Research.

All rights reserved. No part of this publication may be reproduced and/or made public, whether by print, photocopy, microfilm or any other means, without the prior permission of the publisher or author.

Wageningen Livestock Research is NEN-EN-ISO 9001:2015 certified.

All our research commissions are in line with the Terms and Conditions of the Animal Sciences Group. These are filed with the District Court of Zwolle.

Wageningen Livestock Research Report 1122 



\section{Table of contents}

$\begin{array}{ll}\text { Summary } & 6\end{array}$

1

$\begin{array}{ll}\text { Introduction } & 8\end{array}$

$\begin{array}{lll}1.1 & \text { Background } & 8\end{array}$

1.2 Aims $\quad 8$

2

$\begin{array}{ll}\text { Material and methods } & 9\end{array}$

2.1 Experimental animals 9

2.2 Experimental treatments and design 9

2.3 Experimental diets and feeding 9

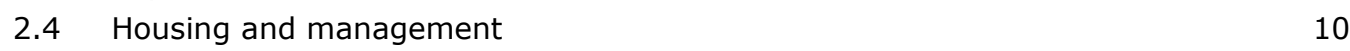

\begin{tabular}{ll}
2.5 & Observations during the study \\
\hline
\end{tabular}

$\begin{array}{ll}2.6 & \text { Description of analytical methods } \\ 2.7 & 10\end{array}$

$\begin{array}{lll}2.7 & \text { Statistics } & 11\end{array}$

3

$\begin{array}{ll}\text { Results } & 12\end{array}$

3.1 General 12

3.2 Health and medical treatments 12

$\begin{array}{lll}3.3 & \text { Growth performance } & 13\end{array}$

$\begin{array}{lll}3.4 & \text { Faecal consistency } & 14\end{array}$

4 Discussion $\quad 16$

$\begin{array}{lll}4.1 & \text { Effect of plasma } & 16\end{array}$

4.2 Factors influencing the response to plasma 16

$\begin{array}{ll}4.3 \text { Effect of zinc oxide } & 17\end{array}$

$\begin{array}{llr}5 & \text { Conclusions } & 18\end{array}$

$\begin{array}{ll}\text { References } & 20\end{array}$

$\begin{array}{lll}\text { Appendix } 1 & \text { Composition of diets } & 22\end{array}$

Appendix 2 Products sheets of Proglobulin P and Protastar potato protein 24 


\section{Summary}

This study was conducted to determine the effect of the inclusion of dried porcine plasma in the diet of weaned pigs, in comparison to the use of a pharmaceutical dose of zinc oxide $(\mathrm{ZnO})$. The study was conducted during a five-week nursery period with six treatment groups, each comprising 12 pens with 12 pigs, males and females mixed. The pigs received a prestarter diet and a starter diet during week 1-2 and week 3-5, respectively, formulated to meet the nutrient requirements in each period. The dietary treatments are summarised in the table below. Porcine plasma was included at the expense of an equal amount of purified potato protein (Protastar). Crystalline amino acids, including isoleucine, were used to assure that all diets met the nutrient recommendations.

\begin{tabular}{llll} 
Treatment & Week 1-2 & Week 3-4 & Week 5 \\
T1 & control & control & control \\
\hline T2 & 2500 ppm ZnO & control & control \\
\hline T3 & $5.0 \%$ plasma & control & control \\
\hline T4 & $2.5 \%$ plasma & control & control \\
\hline T5 & $5.0 \%$ plasma & $2.5 \%$ plasma & $1 \%$ plasma \\
\hline T6 & $2.5 \%$ plasma & $1.25 \%$ plasma & $0.5 \%$ plasma \\
\hline
\end{tabular}

1) All diets were formulated to meet the nutrient requirements of weaned pigs.

Both the inclusion of plasma and $\mathrm{ZnO}$ enhanced the feed intake and growth rate of the piglets, without significant effect on the feed conversion ratio. Use of the pharmaceutical dose of ZnO increased the feed intake and daily gain by $23 \%$ and $29 \%$ relative to the control treatment in week $1-2$ post weaning, without significant effect thereafter. The feed intake and growth rate of piglets receiving diets with $5 \%$ plasma were $11 \%$ and $14 \%$ higher than the control in week $1-2$, respectively. The growth performance of the piglets receiving $2.5 \%$ plasma was intermediate between the $5 \%$ level and the control treatment. Despite some numerical differences, the growth performance from Day 15 to 35 was not significantly affected by the dietary treatments. Over the entire nursery period, the growth performance and final body weight were similar for the treatments with ZnO (T2) and the gradual reduction of plasma from 5 to $1 \%$ (T5) and significantly higher than the control treatment with $5 \%$ potato protein (T1). Both treatments enhanced the final body weight by approximately $1 \mathrm{~kg}$. The results of the other treatments were intermediate. Only the inclusion of ZnO improved the faecal consistency of the piglets, reducing the percentage of piglets with soft faeces and diarrhoea. In the discussion results are compared with studies published in scientific literature and related to feed materials used in the exchange with plasma, and the sanitary conditions on the farm.

From this study it was concluded that:

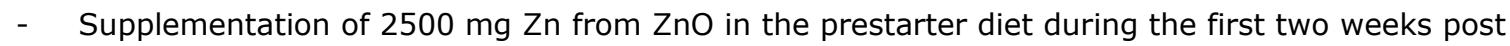
weaning significantly increased feed intake and daily gain in these two weeks and in the total fiveweek nursery period.

- $\quad$ Use of 5\% plasma in the prestarter diet significantly increased feed intake and daily gain in the first two weeks post weaning.

- Use of $5 \%$ plasma in the prestarter diet in the first two weeks, gradually reduced to $2.5 \%$ in week 3 and 4 and $1 \%$ in week 5 additionally increased the daily gain and feed intake in the five week nursery period. Growth performance of pigs receiving these diets was equal to that of pigs of the ZnO treatment.

- $\quad$ Removal of plasma from the diet after two weeks did not reduce the growth performance in comparison to the control treatment.

- $\quad$ Supplementation of $2500 \mathrm{mg} \mathrm{Zn}$ from ZnO in the prestarter diet improved the faecal consistency of the pigs during the first two weeks post weaning and during the total nursery period.

- $\quad$ The faecal consistency was not affected by inclusion of plasma in the diet. 


\section{Introduction}

\section{$1.1 \quad$ Background}

Spray dried blood plasma has demonstrated beneficial effects on growth performance of weaned pigs. However, withdrawal of plasma may result in a transient reduction in performance and a partial loss of the beneficial effect. Therefore Darling Ingredients requested a proposal to validate the effect of plasma in weaned pigs, determine the effect of inclusion level and the effect of a gradual reduction of plasma inclusion in the diet. Because of the expected ban on the use of pharmaceutical levels of zinc oxide ( $\mathrm{ZnO}$ ), it was suggested to include $\mathrm{ZnO}$ in a positive control diet to compare the effect of $\mathrm{ZnO}$ and plasma on growth performance and faecal consistency of the pigs.

\subsection{Aims}

The aims of this study are:

- $\quad$ to determine the effect of level of plasma in the diet of weaned pigs on performance and faecal consistency

- $\quad$ to compare the effects of plasma with the inclusion of a pharmaceutical dosage of ZnO during the first two weeks post weaning

- $\quad$ to determine the effect of a gradual reduction and withdrawal of plasma from the diet of weaned pigs 


\section{Material and methods}

\section{$2.1 \quad$ Experimental animals}

This study was conducted with weaned pigs, equal numbers of entire male and female animals of Tempo x (Dutch Landrace $\times$ Great Yorkshire) breed from the closed herd of the Swine Innovation Centre Sterksel of Wageningen University \& Research. Healthy animals with a weaning weight of 6-10 $\mathrm{kg}$ at about 27 days of age were selected for this experiment. Piglets showing signs of ill-health, injury or being in poor condition were excluded from the selection process. The total number of animals was 864 piglets, selected from three weaning batches (periods). The piglets were uniquely identified by plastic ear-tags.

\subsection{Experimental treatments and design}

This experiment was conducted during a five week period post weaning. The experimental treatments included diets with or without $\mathrm{ZnO}$ and one of two levels of spray dried blood plasma added to the control diet without ZnO. The experimental treatments (T1 to T6) have been summarized in Table 1. In two treatments ( $\mathrm{T} 5$ and $\mathrm{T} 6$ ) the plasma inclusion was gradually decreased to minimise a possible transient decrease in performance or faecal consistency. The experiment comprised 6 treatments with 12 replicates (pens) per treatment and 12 newly weaned piglets per pen. The experiment was replicated over time in three successive batches (periods), with 4 replicates per batch. At the day of weaning (Day 0) piglets were blocked on the basis of sex, weaning weight and litter of origin and randomly allocated to pens such that the six pens within a block had similar mean body weight. The six pens of a block were housed in one room in which pens were randomly allocated to the treatments.

Tabel 1 Dietary treatments (T1 to T6) with dietary plasma content in the respective periods ${ }^{1)}$

\begin{tabular}{llll} 
Treatment & Week 1-2 & Week 3-4 & Week 5 \\
T1 & control & control & control \\
\hline T2 & 2500 ppm ZnO & control & control \\
\hline T3 & $5.0 \%$ plasma & control & control \\
\hline T4 & $2.5 \%$ plasma & control & control \\
\hline T5 & $5.0 \%$ plasma & $2.5 \%$ plasma & $1 \%$ plasma \\
\hline T6 & $2.5 \%$ plasma & $1.25 \%$ plasma & $0.5 \%$ plasma
\end{tabular}

1) All diets were formulated to meet the nutrient requirements of weaned pigs.

\subsection{Experimental diets and feeding}

The experiment started at weaning. From Day 0 to 14 and Day 14 to 35, the pigs received the prestarter and starter diets of their respective treatments (Annex 1). Plasma protein was included at the expense of a protein rich plant based ingredient, purified potato protein (Protastar). Diets were equal in calculated apparent ileal digestible (AID) amino acid content (lysine, methionine plus cysteine, threonine, tryptophan, valine) using synthetic amino acids. The ratio AID isoleucine to lysine decreased from 0.60 to 0.54 when $2.5 \%$ plasma was included in the diet. In the $5 \%$ plasma diet pure isoleucine was used to keep this ratio at a minimum of 0.54 to meet the requirements of the pigs. The nutrient contents of the diets were in agreement with CVB (2012) recommendations and those commonly used in commercial practice. Experimental diets were produced by a feed production plant for research diets ( $A B Z$ Diervoeding in Leusden) using a double mixing procedure to assure equal composition of the two diets. A basal mixture for each of the two phases was prepared and split into four (prestarter diets) and five (starter diets) portions with similar composition, to which ZnO and 
plasma in the required amount was added. Diets were prepared in order of increasing plasma content. The treatment with $\mathrm{ZnO}$ was produced latest to avoid carry-over in another diet. The diets were pelleted in $3 \mathrm{~mm}$ pellets at a maximum temperature of $80^{\circ} \mathrm{C}$. Samples of the pelleted diets were continuously taken by an automatic sampling device and analysed for DM and CP prior to the start of the experiment. Experimental diets were stored in labelled $20 \mathrm{~kg}$ bags. All diets contained $160 \mathrm{mg}$ of $\mathrm{Cu}$ from $\mathrm{CuSO}_{4}$. In the prestarter diet of treatment 2, $2500 \mathrm{mg} \mathrm{Zn}$ from ZnO per $\mathrm{kg}$ was included as Feedmix Gutal ${ }^{\circ}$ 58\% (Huvepharma NV).

The piglets had free access to pelleted diets from dry feeders with two eating places per pen. Water was also freely available from nipple drinkers.

\subsection{Housing and management}

The experiment was conducted in a house for weaned piglets in climate-controlled rooms with a central corridor and four pens on each side. The pens had a surface area of $4.8 \mathrm{~m}^{2}\left(0.4 \mathrm{~m}^{2}\right.$ per piglet based on 12 piglets/pen) with plastic coated mesh floors, plastic fences and feeders of aluminium or stainless steel. Environmental conditions during the trial (temperature and ventilation rate) were computer-controlled and appropriate for the age of the piglets. Standard management and husbandry practices were applied throughout the experiment under the control of experienced personnel. The piglets were monitored daily for any abnormalities, such as abnormal behaviour and clinical signs of sickness. All deviations from normal and required medical treatments were recorded. Piglets were individually medicated only if necessary in case of poor health. Any piglet removed from the trial because of poor health or death was weighed and the date and reason for removal recorded, based on judgement of the farm staff.

\subsection{Observations during the study}

\subsubsection{Performance and health}

Individual body weight of the piglets was recorded at Day 0 (day before weaning, i.e. start of the trial period), Day 14 (diet change-over from pre-starter to starter diets), and Day 35 (end of dietary treatment period). Feed residuals were recorded on these days as well and additionally on Day 28. From these data average daily feed intake (ADFI), average daily gain (ADG), and feed conversion ratio (FCR) were calculated for the two-week periods Day 0-14, Day 15-35, and the complete experimental period Day 0-35. Faecal consistency was recorded three times each week. In each pen, the pigs were categorised in one of three categories: normal faeces, soft faeces and watery diarrhoea. The three observations per week were combined per pen to obtain the mean observation per week. Furthermore, signs of poor health, biting of ears, tails and other body parts, required medical treatments and mortality were registered daily, including likely reasons for treatment or culling.

\subsection{Description of analytical methods}

Dry matter and nitrogen (crude protein) content were analysed in all experimental diets. After grinding, diets were analysed using official methods described to determine moisture (dry matter) and nitrogen (crude protein). Briefly, dry matter was determined by drying to a constant weight at $103^{\circ} \mathrm{C}$ (ISO, 6496). Crude protein was calculated as $\mathrm{N} * 6.25$ after total $\mathrm{N}$ was determined by combustion according to the Dumas principle (ISO, 16634-1:2008). 


\section{$2.7 \quad$ Statistics}

The data were analysed with analysis of variance as a randomised block design using Genstat statistical software. The pen was the experimental unit for the response parameters. The general model including the random effects of batch and block (replicate) within batch and the fixed effect of dietary treatment was:

in which:

$$
Y_{i j}=\mu+\text { Batch }_{i}+\text { Block }_{j} / \text { Batch }_{i}+\text { Diet }_{k}+e_{i j k}
$$

$$
\begin{aligned}
& \mathrm{Y}_{\mathrm{ijk}} \quad=\text { dependent variable, } \\
& \mu \quad=\text { overall mean } \\
& \text { Batch } \quad=\text { batch effect }(i=1,2,3) \\
& \text { Block } \quad=\text { block effect }(j=1 \ldots 4) \text { within period } \\
& \text { Diet } \text { L }_{k} \quad=\text { effect of dietary treatment, }(j=1 \ldots 6) \\
& \mathrm{e}_{\mathrm{ijk}} \quad=\text { residual error. }
\end{aligned}
$$

This model was used to analyse results of the performance parameters (e.g. body weight, ADG, ADFI and FCR). Analyses were performed for treatments 1-6 to determine the effects of dietary plasma content and $\mathrm{ZnO}$ inclusion. A Fisher protected t-test has been used for comparison of treatment means at an overall treatment effect of $P<0.1$. Pairwise differences are marked with superscripted indices when significant $(P<0.05)$. Number of lost animals and required medical treatments were analysed using a chi-square test. Faecal consistency scorings were analysed using the IRClass procedure of Genstat. 


\section{Results}

\section{$3.1 \quad$ General}

The experiment was largely conducted according to plan without major problems in the period from January to April 2018. The three batches started at weaning on January 10, February 21 and March 14. The batch scheduled to start on January 31 was postponed to February 21 because of an infection among the suckling pigs in the farrowing room in this period. These problems were not observed in the next batch three weeks later. Dry matter and crude protein were determined to monitor diet composition. The analysed dry matter content was between 895 and $905 \mathrm{~g} / \mathrm{kg}$ in the prestarter diets and between 880 and $890 \mathrm{~g} / \mathrm{kg}$ in the starter diets. The analysed crude protein content was between 173 and $178 \mathrm{~g} / \mathrm{kg}$ in the prestarter diets and between 177 and 186 in the starter diets.

\subsection{Health and medical treatments}

In Table 2 the required medical treatments of individual piglets and mortality during the trial period are summarised. In total 106 piglets (12\%) were medicated, and 17 piglets (2\%) died in the experiment. The majority of medical treatments were required because of arthritis $(n=34)$, pneumonia $(n=35)$ and Streptoccocus suis $(n=33)$. Pneumonia $(n=5)$ and Streptococcus suis $(n=8)$, but not arthritis were the major causes of death. The dietary treatments did not significantly affect the number of required medical treatments and mortality of piglets.

Table 2 Influence of the use of ZnO and plasma in nursery diets on required medical treatments and mortality of weaned piglets during a 5-week experimental period.

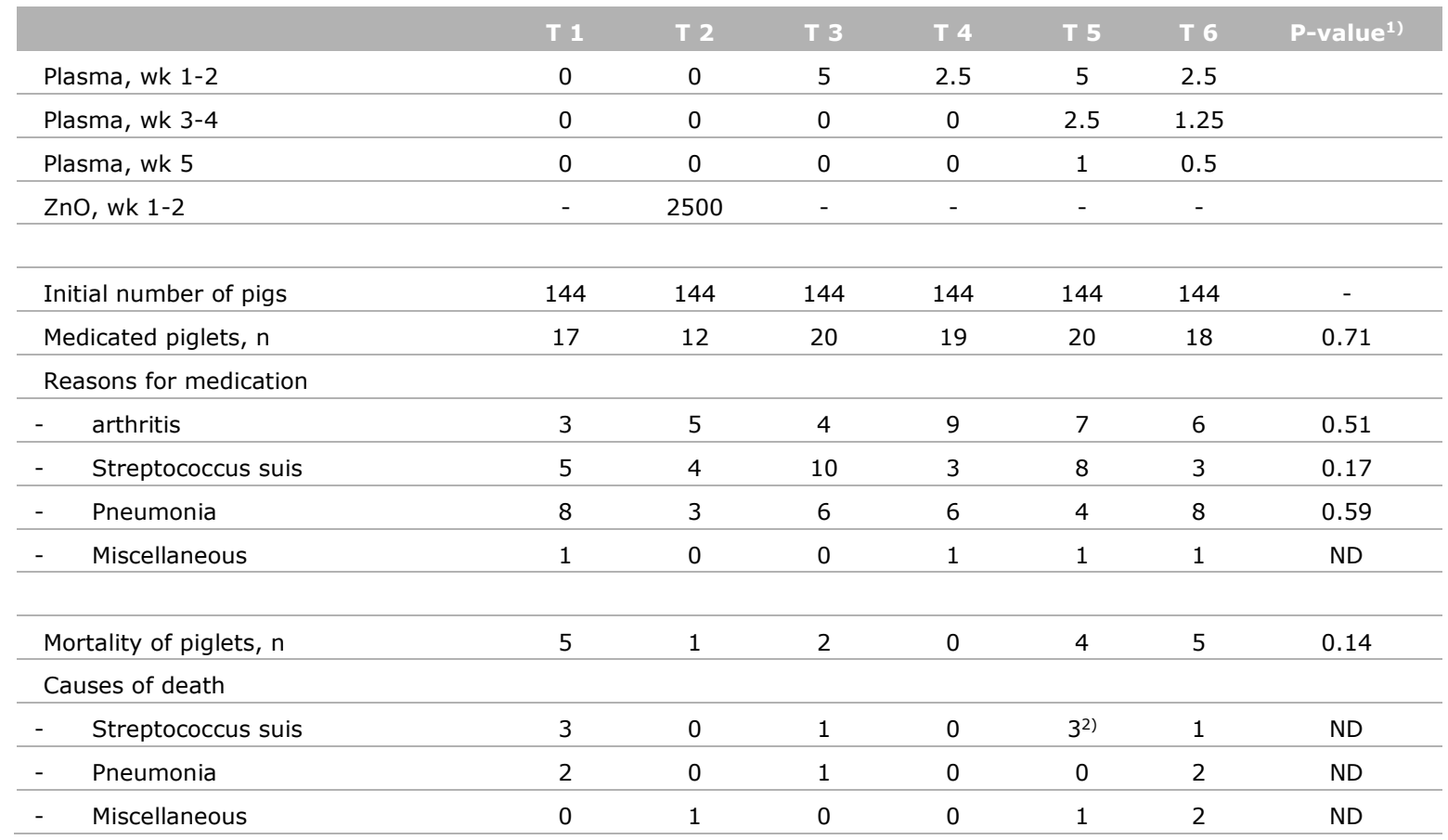

1) P-value, significance of treatment effects. ND, not detectable, number too low for statistical analysis

2) These were three pigs in one pen 


\subsection{Growth performance}

The growth performance of piglets is summarised in Table 3. The initial body weight at weaning was $7.85 \mathrm{~kg}$. The feed intake and daily gain of the pigs from Day $1-14$ were affected $(P<0.001)$ by dietary treatment. The feed intake and gain were $23 \%$ and $29 \%$ higher, respectively, in pigs receiving ZnO supplemented diets (T2) compared to pigs receiving the same diet without ZnO (T1). Feed intake and body gain of these pigs were also higher than pigs of all other treatments. The feed intake and gain of piglets receiving diets with $5 \%$ plasma were $11 \%$ and $14 \%$ higher, respectively, than at the control treatment with purified potato protein. Use of $\mathrm{ZnO}$ and $5 \%$ plasma contributed approximately 0.8 and $0.4 \mathrm{~kg}$ extra body weight on Day 14 after weaning. The growth performance of pigs receiving $2.5 \%$ plasma was intermediate.

Despite some numerical differences, the growth performance from Day 15 to 35 was not significantly affected by the dietary treatments. Over the entire nursery period, the growth performance and final body weight were similar for the treatments with $\mathrm{ZnO}$ (T2) and the gradual reduction of plasma from 5 to $1 \%$ (T5) and significantly higher than the control treatment with $5 \%$ potato protein (T1). Both treatments enhanced the final body weight by approximately $1 \mathrm{~kg}$. The results of the other treatments were intermediate. 
Table 3 Influence of the use of ZnO and plasma in nursery diets on growth performance of weaned piglets during a 5-week experimental period.

\begin{tabular}{|c|c|c|c|c|c|c|c|c|}
\hline & $\mathrm{T} 1$ & T 2 & T 3 & T 4 & T 5 & T 6 & SEM $^{1}$ & P-value 2 \\
\hline Plasma, wk 1-2 & 0 & 0 & 5 & 2.5 & 5 & 2.5 & & \\
\hline Plasma, wk 3-4 & 0 & 0 & 0 & 0 & 2.5 & 1.25 & & \\
\hline Plasma, wk 5 & 0 & 0 & 0 & 0 & 1 & 0.5 & & \\
\hline ZnO, wk 1-2 & - & 2500 & - & - & - & - & & \\
\hline Pens, $\mathrm{n}$ & 12 & 12 & 12 & 12 & 12 & 12 & & \\
\hline \multicolumn{9}{|l|}{ Body weight, kg } \\
\hline Day 0 & 7.86 & 7.85 & 7.85 & 7.85 & 7.85 & 7.84 & 0.006 & 0.349 \\
\hline Day 14 & $10.70^{a}$ & $11.52^{c}$ & $11.07^{\mathrm{b}}$ & $10.93^{\mathrm{ab}}$ & $11.09^{b}$ & $10.77^{a}$ & 0.099 & $<0.001$ \\
\hline Day 35 & $21.28^{a}$ & $22.29^{b}$ & $21.66^{\mathrm{ab}}$ & $21.66^{\mathrm{ab}}$ & $22.22^{\mathrm{b}}$ & $21.22^{a}$ & 0.32 & 0.092 \\
\hline \multicolumn{9}{|l|}{ Day $1-14$} \\
\hline Body gain, g/d & $203^{a}$ & $261^{c}$ & $230^{b}$ & $220^{\mathrm{ab}}$ & $231^{b}$ & $209^{a}$ & 7.1 & $<0.001$ \\
\hline Feed intake, $\mathrm{g} / \mathrm{d}$ & $250^{a}$ & $308^{c}$ & $278^{b}$ & $266^{\mathrm{ab}}$ & $276^{b}$ & $253^{a}$ & 6.9 & $<0.001$ \\
\hline FCR & 1.24 & 1.18 & 1.21 & 1.22 & 1.20 & 1.21 & 0.018 & 0.354 \\
\hline \multicolumn{9}{|l|}{ Day 15-35 } \\
\hline Body gain, g/d & 504 & 513 & 504 & 511 & 530 & 498 & 12.5 & 0.547 \\
\hline Feed intake, g/d & 719 & 737 & 725 & 750 & 753 & 722 & 15.2 & 0.452 \\
\hline FI day $15-28, \mathrm{~g} / \mathrm{d}$ & 616 & 647 & 627 & 640 & 648 & 625 & 14.7 & 0.557 \\
\hline FI day $29-35, \mathrm{~g} / \mathrm{d}$ & 924 & 915 & 921 & 971 & 963 & 915 & 24.0 & 0.363 \\
\hline FCR & 1.43 & 1.44 & 1.44 & 1.48 & 1.42 & 1.45 & 0.018 & 0.261 \\
\hline \multicolumn{9}{|l|}{ Day 1-35 } \\
\hline Body gain, g/d & $383^{a}$ & $412^{b}$ & $395^{\mathrm{ab}}$ & $395^{a b}$ & $411^{\mathrm{b}}$ & $382^{a}$ & 9.1 & 0.092 \\
\hline Feed intake, $\mathrm{g} / \mathrm{d}$ & $531^{a}$ & $565^{c}$ & $547^{a b c}$ & $557^{a b c}$ & $562^{b c}$ & $534^{a b}$ & 10.5 & $0.111^{2)}$ \\
\hline FCR & 1.39 & 1.37 & 1.39 & 1.42 & 1.37 & 1.40 & 0.014 & 0.157 \\
\hline
\end{tabular}

\subsection{Faecal consistency}

Faecal consistency was scored three times a week as number of pigs per pen with normal, soft or watery thin faeces. Results as summarised in Table 4 indicate a gradual increase in the proportion of pigs with normal faeces and a reduction of incidence of soft faeces during the time course of the experiment. Dietary treatment significantly affected the faecal consistency, especially in the first two weeks after weaning. The differences were largely due to the effect of the ZnO supplementation of the prestarter diet (T2). The proportion of pigs with soft faeces in this treatment group in Week 1-2 was approximately $3 \%$ compared to $7 \%$ in pigs of all other treatments. In Week $3-5$, the proportion of pigs with soft faeces was approximately $2.5 \%$ in $\mathrm{T} 2$ and $4.5 \%$ in the other treatments. 
Table 4 Influence of use of ZnO and plasma in nursery diets on faecal consistency of weaned piglets, expressed as percentage of observed piglets (pen basis) in each category during a 5-week experimental period.

\begin{tabular}{|c|c|c|c|c|c|c|c|}
\hline & $\mathbf{T} 1$ & T 2 & T 3 & T 4 & T 5 & T 6 & P-value ${ }^{2}$ \\
\hline Plasma, wk 1-2 & 0 & 0 & 5 & 2.5 & 5 & 2.5 & \\
\hline Plasma, wk 3-4 & 0 & 0 & 0 & 0 & 2.5 & 1.25 & \\
\hline Plasma, wk 5 & 0 & 0 & 0 & 0 & 1 & 0.5 & \\
\hline ZnO, wk 1-2 & - & 2500 & - & - & - & - & \\
\hline Pens, $\mathrm{n}$ & 12 & 12 & 12 & 12 & 12 & 12 & \\
\hline Week 1 & a & $b$ & a & $a b$ & $a b$ & $a b$ & \\
\hline Normal faeces, \% & 90.7 & 95.8 & 92.6 & 94.0 & 92.8 & 93.0 & $<0.001$ \\
\hline Soft faeces, $\%$ & 8.6 & 4.2 & 6.0 & 5.6 & 6.7 & 6.8 & \\
\hline Watery diarrhoea, \% & 0.7 & 0.0 & 1.4 & 0.5 & 0.5 & 0.2 & \\
\hline Week 2 & $\mathrm{a}$ & $\mathrm{b}$ & $\mathrm{a}$ & $\mathrm{a}$ & $\mathrm{a}$ & $\mathrm{a}$ & $<0.001$ \\
\hline Normal faeces, \% & 93.2 & 98.6 & 93.0 & 91.7 & 92.8 & 93.0 & \\
\hline Soft faeces, \% & 6.5 & 1.4 & 7.0 & 8.3 & 7.2 & 6.7 & \\
\hline Watery diarrhoea, \% & 0.2 & 0.0 & 0.0 & 0.0 & 0.0 & 0.2 & \\
\hline Week 3 & a & $\mathrm{b}$ & a & a & $a b$ & a & 0.054 \\
\hline Normal faeces, \% & 91.6 & 95.8 & 92.3 & 90.5 & 93.1 & 91.0 & \\
\hline Soft faeces, \% & 8.2 & 4.2 & 7.4 & 9.5 & 6.7 & 9.0 & \\
\hline Watery diarrhoea, \% & 0.2 & 0.0 & 0.2 & 0.0 & 0.2 & 0.0 & \\
\hline Week 4 & & & & & & & $\mathrm{ND}^{2)}$ \\
\hline Normal faeces, \% & 96.7 & 97.2 & 96.2 & 95.6 & 97.0 & 97.2 & \\
\hline Soft faeces, \% & 3.3 & 2.8 & 3.8 & 4.4 & 3.0 & 2.8 & \\
\hline Watery diarrhoea, \% & 0.0 & 0.0 & 0.0 & 0.0 & 0.0 & 0.0 & \\
\hline Week 5 & & & & & & & $N^{2)}$ \\
\hline Normal faeces, \% & 97.9 & 99.5 & 96.7 & 98.6 & 98.1 & 98.6 & \\
\hline Soft faeces, \% & 2.1 & 0.5 & 3.3 & 1.4 & 1.9 & 1.4 & \\
\hline Watery diarrhoea, \% & 0.0 & 0.0 & 0.0 & 0.0 & 0.0 & 0.0 & \\
\hline Week 1-2 & $\mathrm{a}$ & $\mathrm{b}$ & $\mathrm{a}$ & $\mathrm{a}$ & a & a & $<0.001$ \\
\hline Normal faeces, \% & 92.0 & 97.2 & 92.8 & 92.8 & 92.8 & 93.0 & \\
\hline Soft faeces, \% & 7.6 & 2.8 & 6.5 & 6.9 & 6.9 & 6.7 & \\
\hline Watery diarrhoea, \% & 0.5 & 0.0 & 0.7 & 0.2 & 0.2 & 0.2 & \\
\hline Week 3-5 & $\mathrm{a}$ & $\mathrm{b}$ & $\mathrm{a}$ & $\mathrm{a}$ & $\mathrm{a}$ & $\mathrm{a}$ & 0.015 \\
\hline Normal faeces, \% & 95.3 & 97.5 & 95.1 & 94.9 & 96.1 & 95.6 & \\
\hline Soft faeces, \% & 4.6 & 2.5 & 4.8 & 5.1 & 3.9 & 4.4 & \\
\hline Watery diarrhoea, \% & 0.1 & 0.0 & 0.1 & 0.0 & 0.1 & 0.0 & \\
\hline
\end{tabular}

1 P-value, significance of treatment effects.

2 ND, P-value not detectable because of absence of pigs in the class watery diarrhoea 


\section{Discussion}

\subsection{Effect of plasma}

In the present study the inclusion of 5\% plasma significantly enhanced the average daily gain by 28 $\mathrm{g} / \mathrm{d}$ in the first two weeks post weaning. This effect was largely mediated by an increase in feed intake of $28 \mathrm{~g} / \mathrm{d}$ and a numerical reduction in FCR. The numerical effect of the $2.5 \%$ inclusion level was somewhat less than half of this size. These results are in line with numerous studies reporting an increase in growth performance of the pigs in the first two weeks post weaning (Van Dijk et al., 2001; Torrallardona, 2010). Torralardonna (2010) summarised results of 75 trials and determined a mean increase in daily gain of 37 ( $s d 39) \mathrm{g} / \mathrm{d}$, largely due to an increase in feed intake $(41, \mathrm{sd} 39 \mathrm{~g} / \mathrm{d}$ ) when plasma was included in the diet. In those studies, overall the increase in two-week ADG was higher for plasma from porcine origin as used in the present study, compared to animal plasma from unspecified or unknown origin ( 55 versus $27 \mathrm{~g} / \mathrm{d}$ ). Thus porcine plasma may enhance growth performance more than plasma from other species. This effect was also reported by Van Dijk et al. (2001) although with a lower mean difference between effects of porcine and bovine plasma. During the first week postweaning the response in weight gain and feed intake in the studies reviewed by Torrallardona (2010) increased with increasing inclusion level of plasma. Over the two week period, an optimal inclusion level of $4-8 \%$ was suggested without clear dose dependent response. This may indicate that a plasma inclusion level of $2.5 \%$ is insufficient to induce a substantial increase in growth performance as observed in the present study. The inclusion level of $5 \%$ was less than the mean inclusion level of approximately $8 \%$ in the studies reviewed by Torrallardona (2010), but the benefit of an inclusion level above $5 \%$ in a two-week period was not obvious from this review.

\subsection{Factors influencing the response to plasma}

Overall, the increase in growth performance in the first two weeks post weaning with $5 \%$ plasma in the present study was lower than the mean increase in gain in the studies using porcine plasma in Torrallardona (2010). This may be explained by composition of nursery diets and (sanitary) conditions of the experiment. The effect of plasma inclusion may depend on the protein sources replaced in the experimental diets. Van Dijk et al. (2001) reported a bigger effect when plasma replaced soy protein compared to milk protein. Torrallardona (2010) reported that plasma improved the weight gain of piglets to a variable extent when replacing a variety of protein sources. Although the differences between protein sources were not significant, the increase in gain when using plasma was 50-60 g/d when replacing soybean meal, 30-40 g/d when replacing fishmeal and 5-25 g/d when replacing potato, blood, and whey protein. The author suggested that the expected response would reflect the nutritive value of plasma versus the nature of the protein replaced. Notably, this largely depends on the trial design and whether the diets were balanced for differences in contents of (essential) amino acids and other nutrients. Indeed this is the case when diets were not balanced for the nutrient contents of exchanged protein sources. This was not reported and taken into account in their review. Moreover, a higher effect of plasma may be expected when replacing protein sources with suboptimal amino acid pattern or containing anti-nutritional factors, e.g. soy products. In the present study, plasma was included at the expense of purified potato protein, being a high quality protein source with a well balance amino acid pattern and low in anti-nutritional factors as glyco-alkaloids (e.g. solanine). Furthermore, the diet was balanced in digestible amino acids to avoid nutritional deficiencies. In these conditions the observed response to plasma inclusion can be fully related to beneficial (supranutritional) effects of this product, beyond the nutritional value and irrespective of characteristics of the replaced protein source(s). As such, the effect of plasma in the present study can be regarded as the minimum effect and may be higher when replacing protein sources of lower quality or containing anti-nutritional components.

Sanitory conditions may influence the effects of plasma inclusion. Van Dijk (2001) demonstrated that the effect of plasma was negatively related to the growth rate of pigs in the control group. This may 
indicate that in poor sanitary conditions, causing a reduction in growth rate, use of plasma has a bigger effect then in pigs kept under very hygienic circumstances (Coffey and Cromwell, 1995; Stahly et al., 1995; Bergstrom et al., 1997). Moreover, some studies indicate a lower effect of plasma in medicated or antibiotic supplemented diets (Torrallardona et al., 2003; Bikker et al., 2004) whereas others reported additive effects (Bosi et al., 2004). Hence, these interactions may partly explain why some authors reported higher or lower effects of plasma than in the present study. It is widely accepted that the mode of action of plasma presumably is related to the content of bioactive components (i.e. immunoglobulins) that may be active against antigens in the digestive tract, support the integrity of the digestive tract and reduce the immune system activation (inflammatory response) of weaned pigs, reviewed by Tollarradona (2010). This suggests that it may be feasible to use plasma to support gut health of newly weaned pigs, in particular because of the pressure to reduce pharmaceutical levels of trace elements $(\mathrm{Zn}$ and $\mathrm{Cu}$ ) for this purpose and to reduce the use of antibiotic medication.

\subsection{Effect of zinc oxide}

Dietary supplementation with a pharmaceutical dose of zinc oxide has been widely used to prevent post-weaning diarrhoea in piglets. In the EU, this application was only allowed using authorised products on veterinary prescription, depending on national legislation. In the Netherlands, only the veterinary medicinal product Gutal providing $2500 \mathrm{mg} \mathrm{ZnO}$ per kg feed was authorised and used for this purpose in 2016 and 2017. Because of the EU wide ban on this use from June 2017, with a maximum of 5 years to phase it out, inclusion of pharmaceutical levels of $\mathrm{ZnO}$ is no longer allowed in the Netherlands from 2018 onwards. Inclusion of Gutal was used in this study as one of the treatments to determine whether inclusion of plasma in the nursery diet would compensate for a potential effect of $\mathrm{ZnO}$. Use of $\mathrm{ZnO}$ enhanced daily gain and feed intake in agreement with a number of other studies (Poulsen, 1995; Hill et al., 2001), despite the presence of $160 \mathrm{mg} \mathrm{Cu}$ per $\mathrm{kg}$ in the basal diet. Published studies vary with respect to the potential interaction between pharmaceutical dietary supplements of $\mathrm{Cu}$ and $\mathrm{Zn}$. Some studies reported an additional effect (Perez et al., 2011; Shelton et al., 2011) whereas others reported little benefit of the use a pharmaceutical level of both trace elements (Hill et al., 2000; Shelton et al., 2011). Use of ZnO also improved faecal consistency and reduced the incidence of post-weaning diarrhoea as reported in non-infected pigs (Poulsen, 1995; Hill et al., 2000; Ou et al., 2007; Long et al., 2017) and in pigs challenged in an E. coli infection model (Owusu-Asiedu et al. 2003; Heo et al., 2010).

Thus, the present study included a pharmaceutical dose of ZnO (Gutal) to compare its effect with plasma inclusion. Use of ZnO improved growth performance and fecal consistency as reported in other studies discussed above. The results indicate that in week 1-2 post weaning, the effect of $\mathrm{ZnO}$ on growth performance was higher than the effect of plasma inclusion, but in the 5-week period, pigs receiving $5 \%$ followed by $2.5 \%$ plasma performed equally well as the ZnO group and better than the control treatment, with other groups intermediate. The ZnO treatment but not plasma improved the faecal consistency of the pigs. In contrast, some earlier studies reported a beneficial effect of dietary plasma on faecal consistency or incidence of post-weaning diarrhoea (Van der Peet-Schwering et al., 1995; Maribo, 2009) in large scale group-housed piglets or in experimentally infected pigs (OwusuAsiedu et al., 2003). In the latter study, $10 \%$ plasma replacing pea protein isolate was equally effective in reducing souring scores after an E. coli challenge as $2880 \mathrm{mg} / \mathrm{kg} \mathrm{Zn}$ as ZnO. Different factors including dietary conditions, sanitary conditions, and plasma characteristics may be related to differences between the present study and earlier studies. Results of Owusu-Asiedu et al. (2001) with intact and autoclaved SDPP indicate that anti-E. coli antibody content played an important role in mediating the effect in their studies. This may suggest that plasma-characteristics play a role. In studies of Gatnau and Zimmerman (1991), Van der Peet et al. (1995) and Müller et al. (2018) the reported increase in growth performance and reduction in post-weaning diarrhoea may be related to the decrease in plant protein, e.g. soybean and peas, when plasma was included in the diet. Different models, including segregated early weaning of pigs (Cain and Zimmerman, 1997), an E. coli challenge model (Cain and Zimmerman, 1997; Owusu-Asiedu et al., 2003) and mycotoxin contaminated diets (Müller et al., 2018) have been used. Overall, published studies indicate that plasma may reduce postweaning diarrhoea in newly weaned pigs. This result was not substantiated in the present study. It is not fully clarified under what conditions this effect may be expected and optimised. 


\section{Conclusions}

- $\quad$ Supplementation of $2500 \mathrm{mg} \mathrm{Zn}$ from ZnO in the prestarter diet during the first two weeks post weaning significantly increased feed intake and daily gain in these two weeks and in the total fiveweek nursery period.

- Use of 5\% plasma in the prestarter diet significantly increased feed intake and daily gain in the first two weeks post weaning.

- Use of $5 \%$ plasma in the prestarter diet in the first two weeks, gradually reduced to $2.5 \%$ in week 3 and 4 and $1 \%$ in week 5 additionally increased the daily gain and feed intake in the five week nursery period. Growth performance of pigs receiving these diets was equal to that of pigs of the ZnO treatment.

- $\quad$ Removal of plasma from the diet after two weeks did not reduce the growth performance in comparison to the control treatment.

- Supplementation of $2500 \mathrm{mg} \mathrm{Zn}$ from ZnO in the prestarter diet improved the faecal consistency of the pigs during the first two weeks post weaning and during the total nursery period.

- $\quad$ The faecal consistency was not affected by inclusion of plasma in the diet. 


\section{References}

Bosi, P., L. Casini, A. Finamore, C. Cremokolini, G. Merialdi, P. Trevisi, F. Nobili and E. Mengheri. 2004. Spray-dried plasma improves growth performance and reduces inflammatory status of weaned pigs challenged with enterotoxigenic Escherichia coli K88. J. Anim. Sci. 82:1764-1772.

Bergstrom, J. R., J. L. Nelssen, M. D. Tokach, R. D. Goodband, S. S. Dritz, K. Q. Owen and W. B. Nessmith, Jr. 1997. Evaluation of spray-dried animal plasma and select menhaden fish meal in transition diets of pigs weaned at 12 to 14 days of age and reared in different production systems. J. Anim. Sci. 75:3004-3009.

Bikker, P., A. J. van Dijk, A. Dirkzwager, J. Fledderus, M. Ubbink-Blanksma and A. C. Beynen. 2004. The influence of diet composition and an anti-microbial growth promoter on the growth response of weaned piglets to spray dried animal plasma. Livest. Prod. Sci. 86:201-208.

Cain, C. M. and D. R. Zimmerman. 1997. Effect of spray dried plasma (SDP) on fecal shedding of hemolytic escherichia coli (HEC) and rotavirus by pigs in a segregated early-weaned (SEW) enviroment. J. Anim. Sci. 75(Suppl. 1):61(Abstr.).

Coffey, R. D. and G. L. Cromwell. 1995. The impact of environment and antimicrobial agents on the growth response of early-weaned pigs to spray-dried porcine plasma. J. Anim. Sci. 73:2532-2539.

Gatnau, R. and D. R. Zimmerman. 1991. Spray dried porcine plasma (SDPP) as a source of protein for weanling pigs in two environments. J. Anim. Sci. 69(Suppl. 1):103(Abstr.).

Heo J. M., J. C. Kim, C. F. Hansen, B. P. Mullan, D. J. Hampson, H. Maribo, N. Kjeldsen, J. R. Pluske. 2010. Effects of dietary protein level and zinc oxide supplementation on the incidence of postweaning diarrhoea in weaner pigs challenged with an enterotoxigenic strain of Escherichia coli. Livestock Science 133, 210-213

Hill, G. M., D. C. Mahan, S. D. Carter, G. L. Cromwell, R. C. Ewan, R. L. Harrold, A. J. Lewis, P. S. Miller, G. C. Shurson, and T. J. Veum. 2001. Effects of pharmacological concentrations of zinc oxide with or without the inclusion of an antimicrobial agent on nursery pig performance. J. Anim. Sci. 79:934-941.

Hill, G. M., G. L. Cromwell, T. D. Crenshaw, C. R. Dove, R. C. Ewan, D. A. Knabe, A. J. Lewis, G. W. Libal, D. C. Mahan, G. C. Shurson, L. L. Southern, and T. L. Veum. 2000. Growth promotion effects and plasma changes from feeding high dietary concentrations of zinc and copper to weanling pigs (regional study). J. Anim. Sci. 78:1010-1016.

Long, L., J. Chen, Y. Zhang, X. Liang, H. Ni, B. Zhang. 2017. Comparison of porous and nano zinc oxide for replacing high-dose dietary regular zinc oxide in weaning piglets. PLoS ONE 12(8):e0182550.

Maribo, H. 2009. Daka Porcine Plasma and zinc for weaners. Danish Pig Production. Report no. 846.

Müller, L.K.F., D. Paiano, J. Gugel, W. R. Lorenzetti, J. M. Santurio, F. de Castro Tavernari, E. M. da Gloria, M. D. Baldissera, and A. S. Da Silva. 2018. Post-weaning piglets fed with different levels of fungal mycotoxins and spray-dried porcine plasma have improved weight gain, feed intake and reduced diarrhea incidence

Ou, D., D. Li, Y. Cao, X. Li, J. Yin, and S. Qiao. 2007. Dietary supplementation with zinc oxide decreases expression of the stem cell factor in the small intestine of weanling pigs. Journal of Nutritional Biochemistry 18:820-826.

Owusu-Asiedu, A., C. M. Nyachoti, R. R. Marquardt. 2003. Response of early-weaned pigs to an enterotoxigenic Escherichia coli (K88) challenge when fed diets containing spray-dried porcine plasma or pea protein isolate plus egg yolk antibody, zinc oxide, fumaric acid, or antibiotic. J. of Anim. Sci. 81:1790-1798.

Pérez, V. G., A. M. Waguespack, T. D. Bidner, L. L. Southern, T. M. Fakler, T. L. Ward, M. Steidinger and J. E. Pettigrew. 2011. Additivity of effects from dietary copper and zinc on growth performance and fecal microbiota of pigs after weaning. J. of Anim. Sci. 89:414-425.

Poulsen, H. D. 1995. Zinc oxide for weanling piglets. Acta Agric. Scand. 45:159-167.

Shelton, N. W., M. D. Tokach, J. L. Nelssen, R. D. Goodband, S. S. Dritz, J. M. DeRouchey, and G. M. Hill. 2011. Effects of copper sulfate, tri-basic copper chloride, and zinc oxide on weanling pig performance. J. Anim. Sci. 89:2440-2451. 
Stahly, T. S., D. R. Cook, S. G. Swenson, N. H. Williams and D. R. Zimmerman. 1995. Growth responses of pigs to dietary plasma protein $(\mathrm{pp})$ additions as influenced by pig antigen exposure and pp source. J. Anim. Sci. 73(Suppl. 1):81(Abstr.).

Torrallardona, D. 2010. Spray dried animal plasma as an alternative to antibiotics in weanling pigs-a review. Asian Aust. J. Anim. Sci. 23:131-148.

Van der Peet-Schwering, C. M. C., and G. P. Binnendijk. 1995. The effect of spray-dried porcine plasma in diets with different protein sources on the performance of weanling piglets. Report P1.137 Praktijkonderzoek Varkenshouderij, Rosmalen, The Netherlands.

Van der Peet-Schwering, C. M. C., and G. P. Binnendijk. 1997. Spray dried porcine and bovine plasma and animal and plant protein in diets of weaned piglets. Report P1.185 Praktijkkonderzoek Varkenshouderij, Rosmalen, The Netherlands.

Van Dijk, A. J., H. Everts, M. J. A. Nabuurs, R. J. C. F. Margry, and A. C. Beynen. 2001. Growth performance of weanling pigs fed spray-dried animal plasma: A review. Livest. Prod. Sci. 68:263274. 


\section{Appendix 1 Composition of diets}

Composition of prestarter diets, supplied in week 1 and 2 after weaning

\begin{tabular}{|c|c|c|c|c|}
\hline Treatment & $\mathrm{T} 1$ & T2 & T3 and T5 & T4 and T6 \\
\hline Barley & 30.00 & 30.00 & 30.00 & 30.00 \\
\hline Wheat & 34.70 & 34.20 & 35.00 & 34.90 \\
\hline Maize & 14.82 & 14.82 & 14.82 & 14.82 \\
\hline Soybean meal (hipro) & 3.00 & 3.00 & 3.00 & 3.00 \\
\hline Soycomil P & 2.59 & 2.59 & 2.59 & 2.59 \\
\hline Palm oil & 1.02 & 1.02 & 0.83 & 0.92 \\
\hline Soybean oil & 0.50 & 0.50 & 0.50 & 0.50 \\
\hline Delatosed wheypowder & 4.00 & 4.00 & 4.00 & 4.00 \\
\hline Calcium carbonate & 0.96 & 0.96 & 0.96 & 0.96 \\
\hline Monocalcium phosphate & 0.69 & 0.69 & 0.69 & 0.69 \\
\hline Sodium bicarbonate & 0.47 & 0.47 & 0.08 & 0.27 \\
\hline Salt & 0.15 & 0.15 & 0.11 & 0.13 \\
\hline DL-Methionine & 0.12 & 0.12 & 0.15 & 0.13 \\
\hline L-Lysine- $\mathrm{HCl}$ & 0.40 & 0.40 & 0.36 & 0.38 \\
\hline L-Threonine & 0.09 & 0.09 & 0.11 & 0.10 \\
\hline L-Tryptophan (20\%) & 0.21 & 0.21 & 0.18 & 0.19 \\
\hline Valine $(10 \%)$ & 0.00 & 0.00 & 0.28 & 0.14 \\
\hline L-Isoleucine & 0.00 & 0.00 & 0.06 & 0.00 \\
\hline Premix $^{1)}$ & 0.85 & 0.85 & 0.85 & 0.85 \\
\hline Phytase premix ${ }^{2)}$ & 0.43 & 0.43 & 0.43 & 0.43 \\
\hline Purified potato protein & 5.00 & 5.00 & 0.00 & 2.50 \\
\hline Proglobulin P & 0.00 & 0.00 & 5.00 & 2.50 \\
\hline Feedmix Gutal 58\% ZnO & 0.00 & 0.50 & 0.00 & 0.00 \\
\hline total & 100.0 & 100.0 & 100.0 & 100.0 \\
\hline \multicolumn{5}{|l|}{ Calculated nutrients, $\mathrm{g} / \mathrm{kg}$} \\
\hline Dry matter, analysed & 903 & 895 & 899 & 897 \\
\hline Crude protein & 171 & 170 & 173 & 172 \\
\hline Crude protein, analysed & 173 & 176 & 178 & 175 \\
\hline Crude fat & 36 & 36 & 32 & 34 \\
\hline Crude fibre & 28 & 28 & 28 & 28 \\
\hline Ash & 48 & 53 & 50 & 49 \\
\hline Starch & 476 & 473 & 479 & 478 \\
\hline Sugar & 40 & 39 & 40 & 40 \\
\hline $\mathrm{Ca}$ & 6.5 & 6.5 & 6.5 & 6.5 \\
\hline $\mathrm{bCa}$ & 7.1 & 7.1 & 7.0 & 7.0 \\
\hline $\mathrm{P}$ & 4.9 & 4.9 & 4.9 & 4.9 \\
\hline digestible $\mathrm{P}^{3}$ ) & 3.46 & 3.46 & 3.41 & 3.44 \\
\hline $\mathrm{Na}$ & 2.6 & 2.6 & 2.6 & 2.6 \\
\hline $\mathrm{K}$ & 6.5 & 6.5 & 6.7 & 6.6 \\
\hline $\mathrm{Cl}$ & 3.7 & 3.7 & 3.8 & 3.7 \\
\hline $\mathrm{Cu}, \mathrm{mg} / \mathrm{kg}$ & 162 & 162 & 160 & 161 \\
\hline $\mathrm{Zn}, \mathrm{mg} / \mathrm{kg}$ & 100 & 2432 & 100 & 100 \\
\hline Phytase, FTU & 660 & 660 & 660 & 660 \\
\hline AID LYS & 10.5 & 10.5 & 10.5 & 10.5 \\
\hline AID MET & 3.9 & 3.9 & 3.5 & 3.7 \\
\hline AID MET + CYS & 6.3 & 6.3 & 6.6 & 6.5 \\
\hline AID THR & 6.5 & 6.5 & 6.5 & 6.5 \\
\hline AID TRP & 2.1 & 2.1 & 2.1 & 2.1 \\
\hline AID ILE & 6.3 & 6.3 & 5.7 & 5.7 \\
\hline AID VAL & 7.4 & 7.4 & 7.5 & 7.4 \\
\hline $\mathrm{NE}, \mathrm{MJ} / \mathrm{kg}$ & 9.90 & 9.85 & 9.90 & 9.90 \\
\hline
\end{tabular}

1) Premix provided per $\mathrm{kg}$ of diet: vitamin A, 10,000 IU; vitamin D3, 2,000 IU; vitamin E, $63 \mathrm{IU}$; vitamin $\mathrm{K} 3,0.95 \mathrm{mg}$; riboflavin, $5.0 \mathrm{mg}$; D-pantothenic acid, $11.4 \mathrm{mg}$; niacin, $37.5 \mathrm{mg}$; vitamin B12, $25 \mu \mathrm{g}$; Fe (FeSO4-H2O), $100 \mathrm{mg} ; \mathrm{Zn}$ (ZnSO4-H2O) 78 mg; Mn (MnO), 30 mg; Cu (CuSO4-5H2O), 158 mg; I (KI), 0.5 mg; Se (Na2SeO3-5H2O), 0.25 mg.

2) This premix provided 660 FTU phytase (Axtra® Phytase, Danisco Animal Nutrition) to diets.

3) Apparent total tract digestible phosphorus, assuming no contribution of intrinsic plant phytase 
Composition of starter diets, supplied in week 3 to 5 after weaning

\begin{tabular}{|c|c|c|c|c|c|}
\hline Treatment & T1-T4 & T5, week 3-4 & T5, week 5 & T6, week 3-4 & T6, week 5 \\
\hline Barley & 30.00 & 30.00 & 30.00 & 30.00 & 30.00 \\
\hline Wheat & 33.75 & 34.09 & 33.88 & 33.92 & 33.81 \\
\hline Maize & 11.77 & 11.77 & 11.77 & 11.77 & 11.77 \\
\hline Soybean meal (hipro) & 13.99 & 13.99 & 13.99 & 13.99 & 13.99 \\
\hline Palm oil & 1.14 & 1.04 & 1.10 & 1.09 & 1.12 \\
\hline Soybean oil & 2.00 & 2.00 & 2.00 & 2.00 & 2.00 \\
\hline Calcium carbonate & 1.21 & 1.21 & 1.21 & 1.21 & 1.21 \\
\hline Monocalcium phosphate & 0.84 & 0.84 & 0.84 & 0.84 & 0.84 \\
\hline Sodium bicarbonate & 0.39 & 0.20 & 0.32 & 0.30 & 0.35 \\
\hline Salt & 0.32 & 0.30 & 0.31 & 0.31 & 0.32 \\
\hline DL-Methionine & 0.12 & 0.13 & 0.12 & 0.12 & 0.12 \\
\hline L-Lysine-HCl & 0.39 & 0.37 & 0.38 & 0.38 & 0.39 \\
\hline L-Threonine & 0.12 & 0.13 & 0.12 & 0.13 & 0.12 \\
\hline L-Tryptophan (20\%) & 0.16 & 0.14 & 0.16 & 0.15 & 0.16 \\
\hline L-Isoleucine & 0.00 & 0.00 & 0.00 & 0.00 & 0.00 \\
\hline Premix $^{1)}$ & 0.86 & 0.86 & 0.86 & 0.86 & 0.86 \\
\hline Phytase premix ${ }^{2)}$ & 0.44 & 0.44 & 0.44 & 0.44 & 0.44 \\
\hline Purified potato protein & 2.50 & 0.00 & 1.50 & 1.25 & 2.00 \\
\hline Proglobulin P & 0.00 & 2.50 & 1.00 & 1.25 & 0.50 \\
\hline total & 100.0 & 100.0 & 100.0 & 100.0 & 100.0 \\
\hline \multicolumn{6}{|l|}{ Calculated nutrients, $\mathrm{g} / \mathrm{kg}$} \\
\hline Dry matter, analysed & 888 & 890 & 883 & 884 & 881 \\
\hline Crude protein & 174 & 174 & 174 & 174 & 174 \\
\hline Crude protein, analysed & 180 & 185 & 177 & 186 & 179 \\
\hline Crude fat & 49 & 48 & 49 & 48 & 49 \\
\hline Crude fibre & 31 & 31 & 31 & 31 & 31 \\
\hline Ash & 52 & 52 & 52 & 52 & 52 \\
\hline Starch & 449 & 451 & 450 & 450 & 449 \\
\hline Sugar & 29 & 29 & 29 & 29 & 29 \\
\hline $\mathrm{Ca}$ & 7.5 & 7.5 & 7.5 & 7.5 & 7.5 \\
\hline bCa & 8.1 & 8.0 & 8.1 & 8.1 & 8.1 \\
\hline$P$ & 5.1 & 5.1 & 5.1 & 5.1 & 5.1 \\
\hline dig. $P$ (pellets) & 3.44 & 3.42 & 3.43 & 3.43 & 3.44 \\
\hline $\mathrm{Na}$ & 2.4 & 2.4 & 2.4 & 2.4 & 2.4 \\
\hline $\mathrm{K}$ & 6.6 & 6.6 & 6.6 & 6.6 & 6.6 \\
\hline $\mathrm{Cl}$ & 3.4 & 3.5 & 3.5 & 3.5 & 3.4 \\
\hline $\mathrm{Cu}$ & 164 & 163 & 164 & 164 & 164 \\
\hline $\mathrm{Zn}$ & 105 & 105 & 105 & 105 & 105 \\
\hline Phytase, FTU & 660 & 660 & 660 & 660 & 660 \\
\hline AID LYS & 10.1 & 10.1 & 10.1 & 10.1 & 10.1 \\
\hline AID MET & 3.6 & 3.3 & 3.5 & 3.5 & 3.6 \\
\hline AID MET + CYS & 6.1 & 6.1 & 6.1 & 6.1 & 6.1 \\
\hline AID THR & 6.3 & 6.3 & 6.3 & 6.2 & 6.3 \\
\hline AID TRP & 2.0 & 2.0 & 2.0 & 2.0 & 2.0 \\
\hline AID ILE & 6.0 & 5.5 & 5.7 & 5.8 & 5.9 \\
\hline AID VAL & 6.9 & 6.8 & 6.9 & 6.9 & 6.9 \\
\hline $\mathrm{NE}, \mathrm{MJ} / \mathrm{kg}$ & 9.98 & 9.98 & 9.98 & 9.98 & 9.98 \\
\hline
\end{tabular}

1) Premix provided per kg of diet: vitamin A, 10,000 IU; vitamin D3, 2,000 IU; vitamin E, $63 \mathrm{IU}$; vitamin K3, $0.95 \mathrm{mg}$; riboflavin, $5.0 \mathrm{mg}$; D-pantothenic acid, $11.4 \mathrm{mg}$; niacin, $37.5 \mathrm{mg}$; vitamin B12, 25 g; Fe (FeSO4-H2O), 100 mg; Zn (ZnSO4-H2O) 78 mg; Mn (MnO), 30 mg; Cu (CuSO4-5H2O), 158 mg; I (KI), 0.5 mg; Se (Na2SeO3-5H2O), 0.25 mg.

2) This premix provided 660 FTU phytase (Axtra $®$ Phytase, Danisco Animal Nutrition) to diets.

3) Apparent total tract digestible phosphorus, assuming no contribution of intrinsic plant phytase 
Appendix 2 Products sheets of Proglobulin $P$ and Protastar potato protein 


\section{Sonac Proglobulin ${ }^{\circledR} 80 \mathrm{P}$}

\section{Product description}

Proglobulin $\AA$ is a dried porcine plasma protein, produced from raw material, fit for human consumption. It is an excellent digestible protein source for piglets around weaning. The positive effects of plasma proteins are effectuated by its high palatability and the bio active components, like immunoglobulins. Except for the information under the headline GUARANTEE, the information in this product specification must be read as an indication for animal feed producers.

\section{Physical/Chemical/Microbial Limits}

\begin{tabular}{l|r|r} 
Guarantee & Specifications & Test Method $(*)$ \\
\hline Crude protein $(\mathbf{N} * \mathbf{6}, \mathbf{2 5})$ & min. $800 \mathrm{~g} / \mathrm{kg}$ & ISO 5983:1998 \\
\hline Moisture & max. $90 \mathrm{~g} / \mathrm{kg}$ & ISO 6496:1999 \\
\hline Salmonella & Absence in $25 \mathrm{~g}$ & ISO 6579:2002
\end{tabular}

\begin{tabular}{|c|c|c|}
\hline Standard parameters & Typical Value & Test Method (*) \\
\hline \multicolumn{3}{|l|}{ Weende analysis } \\
\hline Moisture & $80 \mathrm{~g} / \mathrm{kg}$ & ISO $6496: 1999$ \\
\hline Crude ash & $63 \mathrm{~g} / \mathrm{kg}$ & ISO $3329: 1996$ \\
\hline Crude protein $(\mathrm{N} \times 6.25)$ & $810 \mathrm{~g} / \mathrm{kg}$ & ISO 5983:1998 \\
\hline Crude fat (PE) & $2 \mathrm{~g} / \mathrm{kg}$ & CLS \\
\hline \multicolumn{3}{|l|}{ Acids } \\
\hline Citrate & $20 \mathrm{~g} / \mathrm{kg}$ & CLS \\
\hline \multicolumn{3}{|l|}{ Minerals } \\
\hline Calcium & $0,6 \mathrm{~g} / \mathrm{kg}$ & CLS \\
\hline Phosphorus & $0,6 \mathrm{~g} / \mathrm{kg}$ & ISO $6491: 1999$ \\
\hline Magnesium & $0,1 \mathrm{~g} / \mathrm{kg}$ & CLS \\
\hline Potassium & $3 \mathrm{~g} / \mathrm{kg}$ & CLS \\
\hline Sodium & $24 \mathrm{~g} / \mathrm{kg}$ & CLS \\
\hline Sodium chloride & $100 \mathrm{~g} / \mathrm{kg}$ & \\
\hline Chlorine & $37 \mathrm{~g} / \mathrm{kg}$ & \\
\hline \multicolumn{3}{|l|}{ Trace elements } \\
\hline Iron & $55 \mathrm{mg} / \mathrm{kg}$ & CLS \\
\hline Manganese & $1 \mathrm{mg} / \mathrm{kg}$ & CLS \\
\hline Zinc & $10 \mathrm{mg} / \mathrm{kg}$ & CLS \\
\hline Copper & $22 \mathrm{mg} / \mathrm{kg}$ & CLS \\
\hline \multicolumn{3}{|l|}{ Physical data } \\
\hline Solubility & $\min .900 \mathrm{~g} / \mathrm{kg}$ & CLS \\
\hline Bulk density & $350-450 \mathrm{~g} / \mathrm{ltr}$ & CLS \\
\hline $\mathrm{pH}$ & $7-10,6$ & CLS \\
\hline Appearance & $\begin{array}{l}\text { Cream/ white powder } \\
\text { (Agglomerated) }\end{array}$ & Sensorial \\
\hline Taste and odour & Typical for this product & Sensorial \\
\hline
\end{tabular}

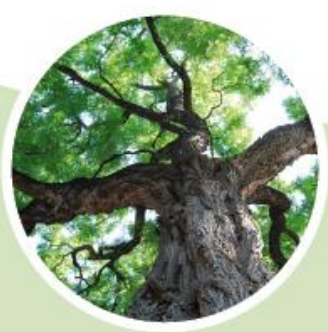

(*) Test method used depends on the country of production of the product $C L S=$ Central Laboratory ERS Son - The Netherlands 


\begin{tabular}{|c|c|}
\hline Amino-acid & $\mathrm{g} / 16 \mathrm{gN}$ \\
\hline \multicolumn{2}{|c|}{ Essential amino-acids } \\
\hline Histidine & 3.1 \\
\hline Leucine & 9.1 \\
\hline Isoleucine & 3.4 \\
\hline Lysine & 8.5 \\
\hline Methionine & 0.7 \\
\hline Phenylalanine & 5.4 \\
\hline Threonine & 5.4 \\
\hline Tryptophan & 1.5 \\
\hline Valine & 6.3 \\
\hline \multicolumn{2}{|c|}{ Non essential amino-acids } \\
\hline Alanine & 5.1 \\
\hline Arginine & 5.5 \\
\hline Aspartic acid & 9.1 \\
\hline Cystine & 3.6 \\
\hline Glutamine & 13.2 \\
\hline Glycine & 3.3 \\
\hline Hydroxylysine & 0 \\
\hline Hydroxyproline & 0 \\
\hline Proline & 5.5 \\
\hline Serine & 5.2 \\
\hline Tyrosine & 6.1 \\
\hline
\end{tabular}

\section{Energy value}

Metabolic energy

\begin{tabular}{l|l}
\hline NE pig & $8.2 \mathrm{MJ} / \mathrm{kg}$ \\
\hline EW pig & $0.94 \mathrm{MJ} / \mathrm{kg}$
\end{tabular}

\section{Packaging}

Multi layer paper bag : $20 \mathrm{~kg} /$ $900 \mathrm{~kg}$ per pallet

Big bag :

$500-1000 \mathrm{~kg}$

Bulk

\section{Custom code: 35040090}

\section{Storage information}

Packed goods: When stored in its original packaging under cool and dry conditions a shelf life of 2 years after production date is guaranteed. With an optimum temperature of $10-25^{\circ} \mathrm{C}$, not above $30^{\circ} \mathrm{C}$. The relative humidity should be below $70 \%$.

Bulk: When stored correctly a shelf life of 2 years after production date is guaranteed. With an optimum temperature of $10-25^{\circ} \mathrm{C}$, not above $30^{\circ} \mathrm{C}$. The relative humidity should be below $70 \%$.

\section{Labeling information}

Proglobulin $($ ) must be labeled as single feedstuff: Plasmapowder. National legislation with regard to usage and labeling should always be verified.

Registered single feed stuff, approved for use in: poultry, pig, fish, pets, fur animals.

Sonac Bad Bramstedt - Tegelbarg 19-21 - 24576 Bad Bramstedt - GERMANY, Approval No. DE0160000308

Contact: Ralf Scheunemann, M: +49 1607052 735, Mail: r.scheunemann@sonac.de www.sonac.biz
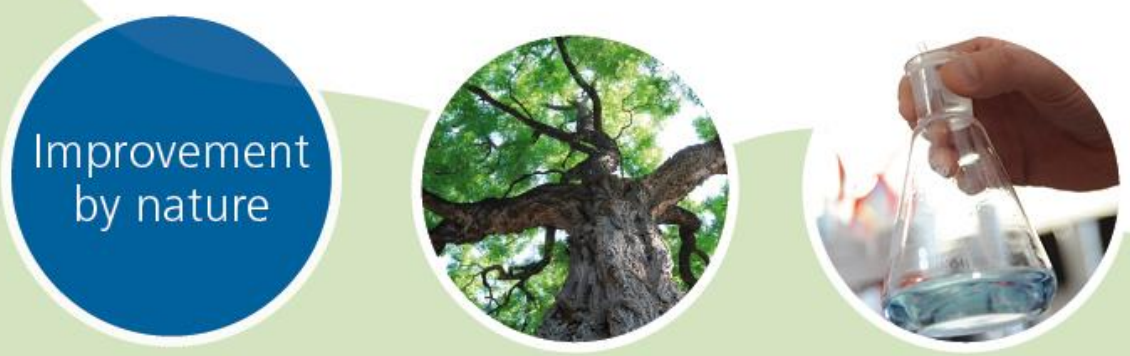


\section{PROTASTAR ${ }^{\circledR}$}

Nutritional value for piglets

(mean values per $\mathrm{kg}$ product as such)

Moisture

Crude protein

795

Crude fat

30

Crude ash

Crude fibre

NFE

Digest. protein (ileal)

Digest. protein (faecal)

il. digest. lysine

g

il. digest. meth

il. digest. meth. + cyst.

il. digest. threonine

g

27.4

il. digest. tryptophan

$\mathrm{P}$

$\mathrm{Na}$

g

$\mathrm{K}$

g

$\mathrm{Cl}$

$\mathrm{Mg}$

GE

MJ

$D E_{S}$

MJ

20.4

$M E_{S}$

$\mathrm{NE}_{\mathrm{S}}$

MJ

MJ

Total aerobic mesophilic count

CFU/g $<50000$

Yeasts

CFU/g $<1000$

Moulds

Escherichia coli

Salmonella $(25 \mathrm{~g})$

CFU/g

$<1000$

CFU/g

$<100$

absent

Diffuse reflection number

$\mathrm{pH}$

Bulk density

$\mathrm{kg} / \mathrm{m}^{3} \quad \pm 500$

The information in this brochure has been compiled in accordance with our best knowledge at the date of issue and is based on recent technological and scientific developments. However, this information should not be construed into recommending the use of our product in violation of any law and/or legalfood standard, any patent or as warranties (express or implied) of non-infringement or its fitness for any particular purpose. Prospective purchasers are invited to conduct their own tests and studies and are advised to verify local legislation and food standards to determine the fitness of AVEBE U.A.'s products for their particular purposes and specific applications. Due to the varying local legislations and applied techniques and conditions applied, AVEBE U.A. accepts no responsibility for any use of the product, may it be by way of experiment or manufacture. Nor does AVEBE U.A. accept any responsibility for the used techniques in any application whatsoever. AVEBE U.A. does not warrant against infringement of laws and/or patents of third parties by reason of any use purchasers make of the product.

The materials displayed in this brochure, including, without limitation, all editorial materials, photographs, illustrations and other graphic materials, and names, logos, trademarks and service marks, are the property of AVEBE U.A. or any of its subsidiaries, affiliates or licensors and are protected by copyright, trademark, and other intellectual property laws. No use of any of these may be made without the prior written authorization of AVEBE U.A., except to identify the products or services of the company. 


\section{AVEBE FEED}

P.O. Box 15

9640 AA Veendam

The Netherlands

FeedInfo@AVEBE.COM

WWW.AVEBE.COM

\section{PROTASTAR ${ }^{\circledR}$}

\section{Amino acid composition for piglets}

(mean values per $\mathrm{kg}$ product as such)

Moisture

$95 \mathrm{~g}$

Crude protein

$795 \mathrm{~g}$

Amino acid profile

$\begin{array}{ccc}\text { in protein } & \text { in product } & \text { ileal digestibility } \\ \mathrm{g} / 16 \mathrm{~g} \mathrm{~N} & \text { as such }(\mathrm{g}) & \text { coefficient }(\%)^{*}\end{array}$

Essential and semi-essential

lysine

methionine

cysteine

threonine

trytophan

valine

leucine

isoleucine

phenylalanine

tyrosine

histidine

arginine

\section{Non-essential}

\section{glycine}

alanine

aspartic acid

glutamic acid

proline

serine

Sum of amino acids $(\mathrm{g})$

meth. + cyst.

phe. + tyr.
8.0

2.5

1.6

6.2

1.5

7.0

10.8

5.9

6.6

6.0

2.2

5.5
63.6

19.9

12.7

49.3

11.9

55.7

85.9

46.9

52.5

47.7

17.5

43.7
93

92

72

91

87

93

94

93

94

95

94

97

*TNO Nutrition and Food Research (ILOB), Wageningen, 1999

The information in this brochure has been compiled in accordance with our best knowledge at the date of issue and is based on recent technological and scientific developments. However, this information should not be construed into recommending the use of our product in violation of any law and/or legalfood standard, any patent or as warranties (express or implied) of non-infringement or its fitness for any particular purpose. Prospective purchasers are invited to conduct their own tests and studies and are advised to verify local legislation and food standards to determine the fitness of AVEBE U.A.'s products for their particular purposes and specific applications. Due to the varying local legislations and applied techniques and conditions applied, AVEBE U.A. accepts no responsibility for any use of the product, may it be by way of experiment or manufacture. Nor does AVEBE U.A. accept any responsibility for the used techniques in any application whatsoever. AVEBE U.A. does not warrant against infringement of laws and/or patents of third parties by reason of any use purchasers make of the product.

The materials displayed in this brochure, including, without limitation, all editorial materials, photographs, illustrations and other graphic materials, and names, logos, trademarks and senvice marks, are the property of AVEBE U.A. or any of its subsidiaries, affiliates or licensors and are protected by copyright, trademark, and other intellectual property laws. No use of any of these may be made without the prior written authorization of AVEBE U.A., except to identify the products or services of the company. 


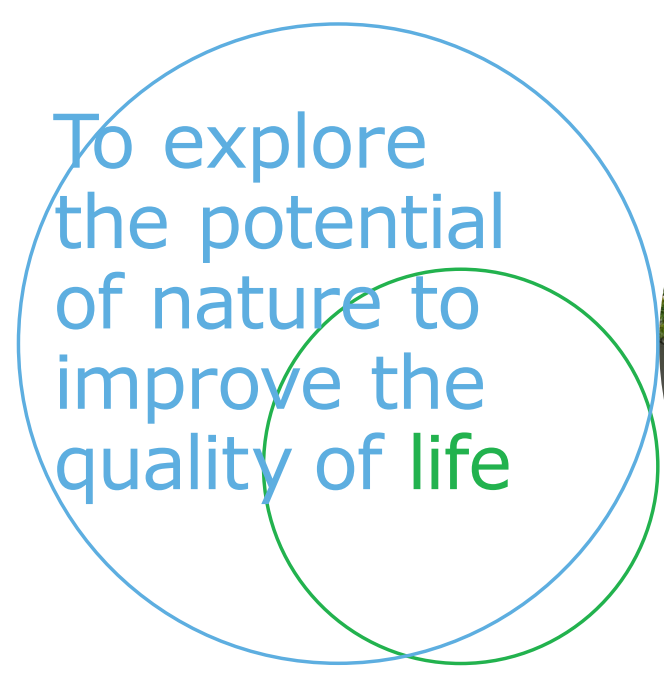

Wageningen Livestock Research P.O. Box 338

$6700 \mathrm{AH}$ Wageningen

The Netherlands

$T+31(0) 317483953$

E info.livestockresearch@wur.nl www.wur.nl/livestock-research

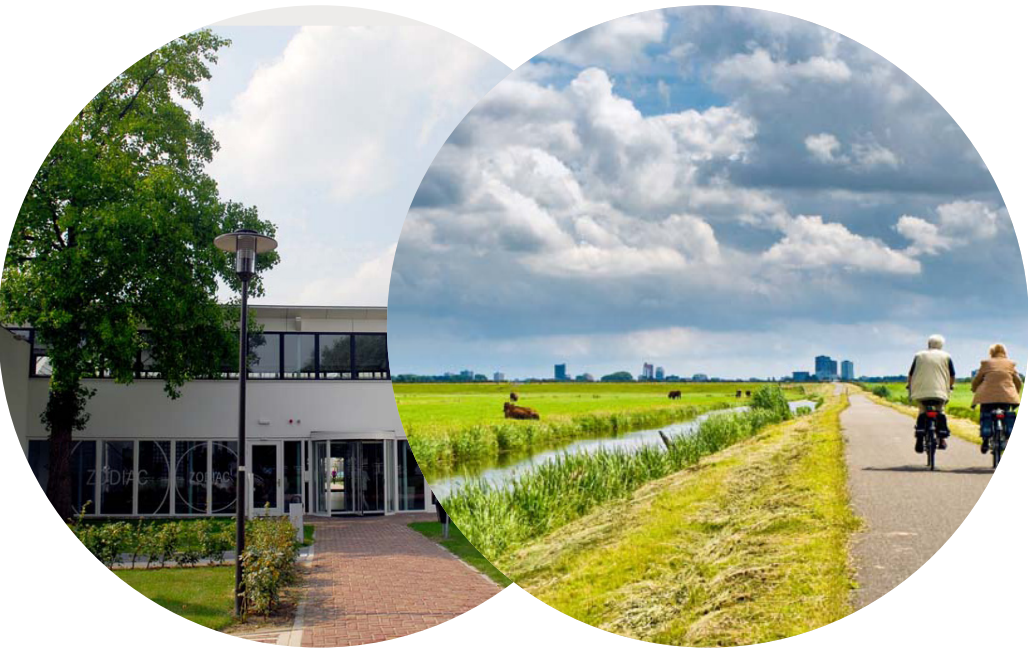

Wageningen Livestock Research creates science based solutions for a sustainable and profitable livestock sector. Together with our clients, we integrate scientific knowledge and practical experience to develop livestock concepts for future generations.

Wageningen Livestock Research is part of Wageningen University \& Research. Together we work on the mission: 'To explore the potential of nature to improve the quality of life'. A staff of 6,500 and 10,000 students from over 100 countries are working worldwide in the domain of healthy food and living environment for governments and the business community-at-large. The strength of Wageningen University \& Research lies in its ability to join the forces of specialised research institutes and the university. It also lies in the combined efforts of the various fields of natural and social sciences. This union of expertise leads to scientific breakthroughs that can quickly be put into practice and be incorporated into education. This is the Wageningen Approach. 